\title{
Grafik Tasarım Öğretiminde Yeni Yöntem Arayışı
}

\author{
Searching for New Approach in Graphic Design Education \\ Kani Ülger \\ Doç. Dr., Cumhuriyet Üniversitesi, Eğitim Fakültesi, Güzel Sanatlar Eğitimi Bölümü \\ email: kulger@gmail.com DORCID ID: https://orcid.org/0000-0001-7435-175X
}

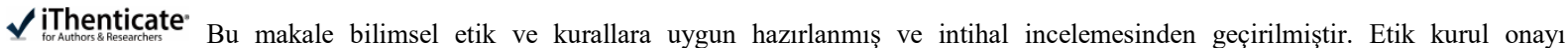
gerektirmemektedir.
\end{abstract}

Atıf (APA 6)/To cite this article

Ülger, K. (2020). Grafik tasarım öğretiminde yeni yöntem arayışı. Atatürk Üniversitesi Güzel Sanatlar Enstitüsü Dergisi, 26(45), 570-579. doi: https://doi.org/10.35247/ataunigsed.749510

Makale Gönderim Tarihi/Received: 08/06/2020

Makale Kabul Tarihi/Accepted: 07/10/2020

Makale Yayın Tarihi/Published: 22/10/2020

Review Article/Derleme Makale

$\ddot{O} z$

Grafik tasarım eğitiminde uygulanan öğretim yöntem ya da teknikler, öğrencilerin tasarım problemlerini çözme ve tasarımlarını geliştirmede etkili olduğu için önemlidir. Bu yolla üretilecek bir grafik tasarım ürünü, hedef kitleyle başarılı bir iletişim kurmada belirleyici olmaktadır. Bu nedenle, günümüz tasarım ihtiyaçlarına cevap verebilecek ve yükseköğretim düzeyinde tasarım öğrencilerinin başarısını arttırmak için yeni öğretim yaklaşımlarının geliştirilmesi gereklidir. Bu yolla, öğrencilerin yeteneklerini geliştirerek, mesleklerinde istenen başarı seviyesine ulaşabilmeleri mümkün olabilir. Günümüz tasarım eğitiminde, öğretim yöntemleri açısından, çağın iletişim unsurlarını destekleyen, öğrencilerin görsel düşünme ve analitik düşünme becerilerini motive eden yeni yaklaşımlara ihtiyaç vardır. Buna göre, araştırmanın problem cümlesi şu şekilde düzenlenmiştir: Yükseköğretim düzeyinde, öğrencilerin grafik tasarım problemlerini analitik düșünme yoluyla çözmelerini destekleyip, onların tasarım ürünlerini geliştirmelerini sağlayacak günümüz grafik tasarım eğitiminde uygulanacak bütüncül bir öğretim yaklaşımı olabilir mi? Bu çalışma, "doküman inceleme" modeli ile yapılmıştır. $\mathrm{Bu}$ model araştırma problemi doğrultusunda ilgili materyallerin analizini içermektedir. Araştırmadan elde edilen verilere göre, grafik tasarım eğitiminde uygulanan yöntemlerin özellikle analitik düşünme yönünden günün koşulları uyarınca geliştirilmesi gerekliliği ortaya çıkarılmıştır. Bu bulgudan yola çıkarak, mevcut öğretim yöntemlerinin günümüz koșullarıyla örtüșen unsurlarını bütünsel bir yaklaşımla ele alındığı yeni bir öğretim yaklaşımı geliştirilebilmesinin mümkün olduğu sonucuna varılmış ve bu doğrultuda önerilerde bulunulmuştur.

Anahtar kelimeler: Grafik Tasarım, Öğretim Teknikleri, Görsel Düşünme.

\begin{abstract}
The methods used in graphic design education are important as they are effective in solving students' design problems and developing their designs. By produced this way, a graphic design will be decisive in establishing a successful communication with the target audience. Therefore, it can be said that teaching methods that can meet the design needs of today are required to increase the success of higher education design students. Thus, it may be possible for design students to achieve their desired level of success by improving their skills. In today's design education, new approaches are needed in terms of teaching methods that support the communication and motivate students' visual thinking and analytical thinking skills. Accordingly, research problem is arranged as follows: Could it be a holistic teaching approach that will be applied in today's graphic design higher education that will enable students to solve their graphic design problems and improve their design products through analytical thinking? "Document analysis" research technique was used in this study. The Document analysis includes materials to examine in accordance with the research question. According to the data obtained from the research, it has been revealed that the methods used in graphic design education should be developed in accordance with the conditions of today especially, in analytical thinking terms. Based on this finding, it is concluded that it is possible to develop a new teaching approach, in which the elements of current teaching methods overlapping today's conditions, are handled with a holistic approach and suggestions were made.
\end{abstract}

Keywords: Graphic Design, Teaching Techniques, Visual Thinking

\section{Giriş}

Grafik tasarımı da içeren "sanat” kavramı oldukça geniş bir kapsama sahiptir. Özsoy ve Alakuş’a (2009, s. 37) göre sanat; duygu yüklü bir anlatımın dışavurumudur. TDK Güncel Türkçe sözlük sanatı: "Bir duygu, tasarı, güzelliğin anlatımında kullanılan yöntemlerin tamamı veya bu anlatım sonucunda ortaya çıkan üstün yaratıcılık" olarak tanımlamaktadır ("Sanat", t.y.). Bununla birlikte, sanat kavramı daha çok görsel sanatları ifade için kullanıldı ̆̆ da bir gerçektir (Dikmen, 2012, s. 139). Görsel sanatlar, bu bağlamda, iki boyutluluk açısından çizim, biçim, renk gibi elemanları kapsarken, üç boyutluluk bakımından da heykel, mimarlık ve düzenlemeleri içeren bir alandır. Özsoy ve Alakuş (2009, s. 392), resim, heykel, seramik, grafik tasarım, mimarlık, endüstriyel tasarım ve modayı görsel sanatlar içinde saymakla birlikte, bu alanın genişletilebileceğinden söz eder. Ayaydın (2009, s. 111) ise sanat eleman ve ilkelerine dikkat çekerek, çizgi, doku, renk, ton, valör (değer), biçim, şekil, mekân ile ritim, denge, vurgu, zitlık, armoni, oran, bütünlük ve çeşitlilik gibi tasarım kavramlarını sanatın görsel dilini oluşturan faktörler olarak belirtir. Sanatın görsel dilini yaygın bir biçimde geniş halk kesimlerine ulaştıran sanat dalı ise grafik sanatlardır.

Grafik terim olarak yazmak, çizmek, görüntülemek ve çoğaltmak anlamına gelmektedir (Tepecik, 2002, s. 17). Görsel sanatlar içinde yer alan grafik sanat dalı, işlev olarak iki ya da üç boyutlu çalışmaları belli bir 
tasarım çerçevesinde gerçekleştirir. Bu bağlamda tasarım; farklı boyutlardaki nesnelerin bir çerçeve içine yerleştirilerek, belirli bir hedef kitle için tutarlı ve maksatlı bir bütün halinde düzenlenmesidir (Margolin ve Buchanan, 1995'den aktaran Cheung, 2011, s. 845). Tasarım, esasında bir plan, hedef, proje, süreç, eskiz, model, motif, tarz ve nihayetinde görsel bir kompozisyondur (De Mozota, 2005'den aktaran Balaban ve Akdağ Satır, t.y., s. 20). Bunun yanında, tasarım ayrıca, hayalde canlandırılan bir düşüncenin iki veya üç boyutlu bir ürün olarak üretilmesini de ifade eder (Tepecik, 2002, s. 27). Tasarım, bir plan, eskiz ya da desenin kompozisyon yoluyla bize görsellik sunarken (De Mozota, 2005'den aktaran Balaban ve Akdağ Satır, t.y., s. 20), önceden işlenebilir duruma getirilmiş materyallerin, belirlenen belli bir ürünü oluşturmak için, çeşitli araç ve gereçlerden yararlanma sürecine de işaret etmektedir (Tepecik, 2002, s. 98). Peng ve Zhang (2014, s. 3), grafik tasarımı bu bağlamda, sanat ve estetik açısından somut ya da soyut bir şeyi, belli işlemler sonucunda ulaşılan bir ürün olarak açıklamaktadır. Özetle, grafik tasarım; oluşturulacak ürün hakkında düşün, plan, yapım aşamalarını içeren ve süreç sonunda özgün bir ürün ortaya konarak, geniş halk kesimlerine bu ürünü sunan bir alan olarak nitelenebilir. Ravikumar (2008), bu nedenle, grafik tasarım ürününü önemli bir iletişim aracı olarak görmektedir. Dolayısıyla, grafik tasarım eğitimi günümüzde önemli bir alan eğitimi olarak görülmektedir. Bu alandaki eğitim, tasarımın gelişimi, yenileşmesi ve kapasitesinin artırımı açısından yaşamsal bir öneme sahiptir (Peng ve Zhang, 2014, s. 4). Bu nedenle, günümüzde grafik tasarım eğitiminde öğrencilerin tasarımlarını sonuçlandırma becerisinin geliştirilmesi için, öğretim yöntem ve tekniklerin eğitim programlarına hızlı bir biçimde girmesi gereklidir (Margolin, 2012, s. 2). Genel anlamda eğitim, hali hazırda, birçok öğretim yönteminin uygulandığı bir alan olmakla birlikte (Becer, t.y.; Kırışoğlu, 2009; Sönmez, 2010), grafik tasarım eğitimi, daha çok görsel problemlerle ilgili olan (Ravikumar, 2008, s. 49) farklı bir alan olduğu için uygulanacak öğretim yöntemlerinde bazı özellikler olması gerekir. Grafik tasarım eğitiminde öğrencinin başarısı, tasarım sürecinde karşılaştığı problemlere getirdiği çözümlere birebir bağlıdır. Bu nedenle, grafik tasarımcılar herhangi bir tasarım ürünü üzerinde çalışırken karşılaştıkları sorunları formüle ederek, çözüm için uygun yöntemler kullanmak zorundadirlar (Cross 1982 ve Dorst ve Dijkhuis 1995'den aktaran Kim, Ju ve Lee, 2015, s. 103). Bu bağlamda, grafik tasarımının başarısı, hedef kitleyle iletişim sağlayabilen tasarımlarla belirlenebileceği söylenebilir (Özderin, 2019, s. 526). Bu durum dikkate alındığında, grafik tasarım eğitiminde, tasarımcı adayı öğrencilerini söz konusu bu iletişimde karşılaşacakları tasarım problemlerini çözme konusunda yetkin hale getirmek önemlidir (Margolin, 2012, s. 1). Böylesi bir yetkinlik ise, grafik tasarım eğitiminde uygulanacak yöntemlerin günün koşullarına uygun biçimde geliştirilmesiyle mümkündür. Rutherford (2015, s.89) öğrencilerin tasarımlarını analitik biçimde değerlendirmelerini teşvik edecek bir yöntem bulunmasının günümüz endüstri-teknolojik karma yaşamına uyum için bir zorunluluk olduğunu belirtmektedir. Yazara göre, yükseköğretim düzeyinde tasarım programlarında bu uyumu başaracak yöntemler bulamazsak, öğrenciler ne yeteneklerini geliştirebilir ne de mesleklerinde istenen başarı seviyesine ulaşabilirler (Rutherford, 2015, s. 89). Dolayısıyla, grafik tasarım öğrencilerinin analitik düşünmelerini motive eden yeni öğretim yöntem ya da yaklaşımlarına yükseköğretim düzeyinde ihtiyaç bulunmaktadır (Vukic, 2012, s. 3). Buna karşın, grafik tasarım eğitiminde, günümüz gelişmişlik düzeyine cevap verebilecek, analitik tasarım çözümleri üretecek, tasarımın hedef kitle ile iletişiminde başarısını arttıracak bir öğretim yöntem ya da yaklaşımın bulunduğunu söylemek zordur.

Bu çalışmanın amacı; grafik tasarım eğitiminde, öğrencinin analitik düşünme yoluyla tasarım sorunlarını çözüp, günümüz grafik tasarım ürün ihtiyacına cevap verebilecek bir öğretim yaklaşımı önermektir. Buna göre, araştırma sorusu şu şekilde düzenlenmiştir: Yükseköğretim düzeyinde, öğrencilerin grafik tasarım problemlerini analitik düşünme yoluyla çözmelerini destekleyip, onların tasarım ürünlerini geliştirmelerini sağlayacak günümüz grafik tasarım eğitiminde uygulanacak bütüncül bir öğretim yaklaşımı olabilir mi?

\section{Yöntem}

\subsection{Araştırmanın Modeli}

Bu çalışma betimsel araştırma yönteminde yapılmıştır. Araştırmanın kapsamı konu ile ilgili yayın ve yapılmış çalışmalardan oluşmaktadır. Bu çalışma "Doküman inceleme" tekniğinde araştırma konusunu içeren materyallerin analizini içermektedir. "Doküman analizi" olarak da adlandırılan model; görsel ve/ya yazılı malzemenin toplanıp incelenmesi olarak tanımlanabilir (Sönmez ve Alacapınar, 2011, s. 83). Araştırma sorusu doğrultusunda belirlenen dokümanların incelenmesine dayalı "Doküman inceleme", veri toplama aracı olarak da kullanılabilir (Cansız Aktaş, 2014, s. 363).

\subsection{Verilerin Analizi}

Araştırma konusu dokümanlar içerik analizine tabi tutularak, kavramlar tanımlanmış, bunlar araştırma sorusu doğrultusunda sınıflandırılmıştır. Böylece doküman analizi sürecinde elde edilen veriler konu ile ilgili noktaları destekleyen veya çelişenleri ortaya çıkaracak biçimde kullanılmıştır (Bailey, 1982 ve Frankel ve Wallen, 2006'dan aktaran Cansız Aktaş, 2014, s. 365). Bu tür bir analizde betimleyici bilgi sağlamak ve bilginin anlaşılır hale 
gelmesine yardımcı olmak gibi sonuçlara ulaşılabilir (Büyüköztürk, Kılıç Çakmak, Akgün, Karadeniz ve Demirel, 2009, s. 264).

\section{Bulgular}

\subsection{Eğitimde ve Grafik Tasarım Eğitiminde Kullanılan Yöntemlere İlişsin Bulgular}

Eğitim alanında işe koşulacak öğrenme-öğretme strateji, yöntem ve teknikleri değiş̧ebilirdir (Sönmez, 2010, s. 15). Sanat alanına özgü farklı öğretim yöntem ve tekniklerin bulunup, uygulanması da olağan bir durumdur (Kırışoğlu, 2009, s. 100). Hali hazırda, genel eğitimde sıklıkla uygulanan Sunuş Yoluyla Öğretim, Buluş Yoluyla Öğretim, Araştırma-Soruşturma Yoluyla Öğretim gibi teknikler mevcuttur (Sönmez, 2010, s. 210). Bununla birlikte, hem genel eğitim hem de sanat alanında uygulanabilen öğretim yöntemleri olarak; anlatım ve işbirliğine dayalı yöntem, soru-yanıt, sorun çözme, gösterme, drama, tartışma, öyküleştirme, grup çalışması ve beyin firtınası öne çıkmaktadır (Kırışoğlu, 2009, s. 102-117). Grafik tasarım eğitiminde ise yaygın olarak altı teknik ya da strateji kullanılmaktadır. Bunlar: Dikey ve Kapsamlı Düşünme, Yaratıcı Grup Toplantılart: (Brainstorming), Kuluçka Tekniği, Not Alma Tekniği, Sentez Yöntemi ve Gözlemler'dir (Becer, t.y., s. 47). Ayrıca, grafik tasarımda Görsel Beyin Firtınası (Visual brainstorming), Grafik tasarımcı ile Beyin Firtınası (Van Der Lugt, 2000, s. 510) ve Linkografi gibi yöntemler de kullanılmaktadır (Kan ve Gero, 2005, s. 230). Bununla birlikte, siralanan bu yöntem ya da tekniklerin, hızlı bir görsel iletişimin yaşandığı günümüzde, grafik tasarım bağlamında işe yarar çözümler getirerek, endüstri-teknolojik gelişmişlik seviyesi hızla artan toplum katmanlarıyla başarılı bir iletişim kurduğu konusu ise tartışmaya açıktır. Tablo 1'de, halen genel eğitimde, sanat eğitiminde ve grafik tasarım eğitiminde kullanılan yöntemler yer verilmiştir.

Tablo 1

Eğitim, Sanat Eğitimi ve Grafik Tasarım Eğitiminde Kullanılan Öğretim Yöntem ve Teknikler

\begin{tabular}{ccc}
\hline $\begin{array}{c}\text { Eğitimde Sıkça Kullanılan Yöntem ve } \\
\text { Teknikler }\end{array}$ & $\begin{array}{c}\text { Sanat Eğitiminde Kullanılan Yöntem ve } \\
\text { Teknikler }\end{array}$ & $\begin{array}{c}\text { Grafik Tasarım Eğitiminde Kullanılan } \\
\text { Yöntem ve Teknikler }\end{array}$ \\
\hline $\begin{array}{c}\text { Sunuş Yoluyla Öğretim } \\
\text { Buluş Yoluyla Öğretim }\end{array}$ & - & $\begin{array}{c}\text { Dikey ve Kapsamlı Düşünme } \\
\text { Yaratıcı Grup Toplantıları (Brainstorming) } \\
\text { Kuluçka Tekniği }\end{array}$ \\
$\begin{array}{c}\text { Araştırma-Soruşturma Yoluyla Öğretim } \\
\text { Anlatım ve İşirliğine Dayalı Yöntem }\end{array}$ & - & Sentez Yöntemi \\
Soru-Yanıt & Anlatım ve İşbirliğine Dayalı Yöntem & Gözlemler \\
Sorun Çözme & Soru-Yanıt & Seming \\
Gösterme & Sorun Çözme & Görsel Beyin Fırtınası (Visual Brainstorming) \\
Drama & Gösterme & Grafik Tasarımcı ile Beyin Fırtınası \\
Tartışma & Drama & Linkografi \\
Öyküleştirme & Tartışma & - \\
Grup Çalışması & Öyküleştirme & - \\
Beyin Fırtınası & Grup Çalışması & - \\
\hline
\end{tabular}

Sunuş yoluyla ögretim: Sunuş yoluyla öğretim stratejisinde, öğretmen önce konuyu sınıfa anlatarak, konu hakkında sorular sorup doğruluğunu veya yanlışlığını sınıfça tartışır. Bu yöntemde öğretmen, doğru yanıt veremeyen öğrencilere ipucu vermesi ve onların doğru yanıtı bulmasını sağlamasıyla süreç devam eder. Bu yöntem, eğitim hayatımız boyunca sıklıkla karşılaştığımız bir yöntemdir. Sunuş yoluyla öğretim yönteminde kullanılan öge sözel'dir. Bu yöntemde varılmak istenen amaç ise; ders konusunu anlama yoluyla soyut kavram oluşturma olarak, nitelenebilir. Bu yöntem öğretim hedeflerine ulaşmak için soru-yanıt yolunu kullanmaktadır.

Buluş yoluyla öğretim: Buluş yoluyla öğretim stratejisinde öğretmen, öğrenciye buldurulacağ1 konu ile ilgili örnekleri sınıfa getirerek, açık-uçlu sorularla bunların yanıtlarını sınıfça tartışmasını sağlar. Öğretmen bu süreçte ipucu verebilir ve yol gösterici olabilir ancak, asıl süreç öğrencinin yapacağı işlemlerle devam eder. Öğrenci konu ile ilgili doğru ya da doğruları bulunana dek süreç sürdürülür. Buluş yoluyla öğretim yönteminde kullanılan ögeler; sözel ve örnekleme'dir. Bu yöntemde ulaşılmak istenen amaç; ders konusunu uygulama yoluyla somut-soyut kavram oluşturma, biçiminde açıklanabilir. Buluş yoluyla öğretim yöntemi, öğretim amacına ulaşmak için, tartışma yolunu kullanmaktadır.

Araştırma-soruşturma yoluyla öğretim: Araştırma-soruşturma yoluyla öğretim stratejisinde öğretmen ilgili problemi öğrencilere sorarak, problem çözme için izlenecek basamakları tahtaya yazar: "Problemde verilenler nelerdir?", “Ístenilen nelerdir?”, “Bu problem nasıl çözülebilir?” gibi basamaklar üzerinden süreç devam ettirilir (Sönmez, 2010, s. 210-289). Araştırma-soruşturma yoluyla öğretim yönteminde kullanılan öge sözel'dir. Bu yöntemde amaç ise; ders konusunu araştırma-işlem ve uygulama yoluyla soyut kavram oluşturma, biçiminde olduğunu söyleyebiliriz.

Anlatım ve işbirliği yolu ile öğrenme: Bu öğrenme yönteminde öğrenciler, birbirleriyle işbirliği içinde, ele alınan problemi çözmeye, özgün bir ürün ortaya çıkarmaya ya da bir konu hakkında bilgi toplamaya çalışırlar. $\mathrm{Bu}$ yöntemde öğrenciler arasındaki etkileşim önemlidir. Bu nedenle, Anlatım ve işbirliği yolu ile öğrenme 
yöntemi işbirliğini destekleyecek etkinlikler içerir. İşbirliği yolu ile elde edilen sonuçlar tartışlarak yorumlanır ve ürün ortaya çıkarılır (“İşbirliğine dayalı”, t.y.). İşbirliği yolu ile öğrenme yönteminde kullanılan öge iletişim'dir. Bu yöntemin amacı; ele alınan konuyu işbirliği ve araşstırma yoluyla somut-soyut kavram oluşturma, biçiminde ifade edebiliriz.

Soru-yanıt yöntemi: Soru-yanıt, öğrencilerin birbirleri arasında belli bir konuda fikirlerini ortaya koyarak, yetkili bir kişinin yönetiminde yapılan sistemli bir tartışma çerçevesinde uygulanır ("Soru-cevap", t.y.). Bu öğretim tekniğinde kullanılan öge sözel'dir. Bu teknikle amaçlanan ise; öğrencilerin ilgili konuyu kendi aralarında, fikir alışverişi biçiminde tartışmasını sağlayarak, soyut kavram oluşturmaktır.

Sorun çözme yöntemi: Sorun çözme yönteminde ilk aşamada problem belirlenir ve çözüm yollarının araştırılmasıyla süreç devam eder. Son aşama ise, problemin çözülme sürecini kapsar ("Problem çözme", t.y.). Sorun çözme yönteminde kullanılan öge çözümleme'dir. Bu yöntemde izlenen amacın; öğrencinin ilgili problemi araştırarak çözme yoluyla somut-soyut kavram oluşturma, biçiminde olduğunu söyleyebiliriz.

Gösterip yaptırma yöntemi: $\mathrm{Bu}$ yöntemde görsel ve işitsel öğeler birlikte kullanılır. Gösterip yaptırma yönteminde öğrencilere bir işin en iyi biçimde nasıl yapılacağı gösterilir ve daha sonra öğrenciden bu işi öğrenme ortamında yapması istenir. Gösterip yaptırma yöntemi daha çok uygulama düzeyindeki psikomotor becerilerin kazandırılması amacıyla kullanılır ("Gösterip yaptırma", t.y.). Bu yönteminde kullanılan ögeler; görsel ve işitsel'dir. Yöntemin amacı ise; ders konusunu uygulama yoluyla somut kavram oluşturmaktır.

Drama tekniği: Drama'da öğrencilerin bir yaşantıyı, olayı, fikri ya da soyut bir kavramı oyunsu süreçlerle canlandırmasıdır ("Drama tekniği”, t.y.). Drama tekniğinin eğitimde bir öğretim yöntemi olarak uygulanmasının amacı; bireylere duygularını, düşüncelerini ve davranışsal yetileri özgürce ifade etme becerisini geliştirmektir ("Drama tekniği”, t.y.; Kara ve Çam, 2007, s. 145). Drama tekniğinde kullanılan ögeler; sözel ve eylem'dir. Bu öğretim tekniğinde amaç; konuyu uygulama yoluyla soyut ya da somut kavram oluşturma, biçiminde ifade edebiliriz.

Tartışma yöntemi: Tartışma yönteminde, 6-10 kişiden oluşan bir öğrenci grubu, bir cümle ya da sorunu kendi aralarında tartışır. Bu tartışmadan çıkan görüş ve öneriler ışığında, sorun hakkında en doğru çözüm bulunmaya çalışılır ("Tartışma yöntemi", t.y., s. 2). Tartı̧̧ma yönteminde kullanılan öge sözel'dir. Bu yöntemde, konu ya da sorunun tartışma yoluyla öğrencide soyut ya da somut kavram oluşturmak amaçlanmaktadır.

Öyküleştirme yöntemi: Öyküleştirme yönteminde öğrenme süreci bir öykü ile başlar. Bu öyküde zaman, mekân, karakter(ler) bağlamında konular bir bütünlük içerisinde işlenir. Yöntem olarak öyküleştirmede öğrencilere anlama ve kavrama becerilerini desteklemek için roller verilir (aktaran Tepetaş ve Haktanır, 2013, s. 65). Öyküleştirme yönteminde kullanılan öge sözel'dir. Bu yöntemden beklenen amaç ise; rol yoluyla öğrencilerde somut-soyut kavram oluşturmaktır.

Grup çalışması yöntemi: Grup çalışması, öğrencilerin işbirliği yaparak, ortak amaçlar doğrultusunda çalışmalarına olanak sağlayan bir yöntemdir (Derviş, 1993'den aktaran Hayırsever, 2002, s. 2). Bu yöntemde temel olan unsur; öğrencilerin öğrenmelerini beslemek için, birbirini anlayan ve destekleyen bir birlikteliğin sağlanmasıdır (Türmen, 1997'den aktaran Hayırsever, 2002, s. 2). Grup çalışması yönteminde kullanılan öge iletişim'dir. Bu yöntemde varılmak istenen amaç ise; ders konusunu işbirliği yoluyla soyut ya da somut kavram oluşturma olarak, açılayabiliriz.

Beyin firtınası tekniği: Beyin firtınası, bireylerin eleştirilme endişesi olmadan, değişik fikirlerin ortaya konulmasını destekleyen bir tekniktir. Bu teknikte katılımcılar, kısa sürede, çok sayıda farklı fikirler üretebilir. Bir sonraki aşamada ise, bu üretilen fikirler listelenir ve bu listeden kullanılabilecek olanlar seçilir (“Öğretim yöntemleri”, t.y.). Bu teknikte amaç; öğrencilerin hayal güçlerini kullanarak, bir soruna birden çok çözüm önerisi geliştirmelerini sağlamaktır ("Beyin Fırtınası", t.y.). Beyin Fırtınası yönteminde kullanılan öge sözel'dir. Bu tekniğin amacı; ilgili konu ya da sorunu çözmek için fikir üretme yoluyla soyut ya da somut kavram oluşturmaktır.

Dikey ve kapsamlı düşünme: Bu öğretim tekniğinde geçen dikey düşünme kavramı; insan düşüncesinin alışılagelen mantıklı düşünme yönünü temsil eder. Kapsamlı düşünme ise, tam tersine, ; insan düşüncesinin denenmeyeni bulma yönüne işaret eder. Dikey ve kapsamlı düşünme öğretim yönteminde kullanılan öge sözel'dir. Bu yöntemde varılmak istenen amaç ise, konuyu düşün (zihin) yoluyla soyut kavram oluşturmaktır.

Yaratıcı grup toplantılarl, brainstorming (Beyin firtınası): Yaratıc1 grup toplantılarında katılımcılar bir konuyla ilgili çok sayıda fikir geliştirirler. Ele alınan konu ya da sorun hakkında çözüm önerileri geliştirirler. Dolayısıyla, bu yönteme bir tür problem çözme tekniği olarak bakabiliriz. Yaratıcı grup toplantılarında kullanılan öge sözel'dir. Bu yöntemde amaç; konu hakkında fikir üretme yoluyla, farklı çözüm yolları geliştirme bağlamında, soyut kavram oluşturmaktır. 
Kuluçka tekniği: Bu teknik, bir tasarım problemi üzerinde belirli süre yoğunlaştıktan sonra, ilgili problem tekrar ele alındığında, bireyin önceden gözden kaçırdığı noktaların ayırımına vardığı bir süreci içerir. Dolayısıyla, kuluçka tekniği, ele alınan sorunun çözümünde belli bir sürenin geçmesi gerektiği ilkesine dayanır. Bu teknikte, ele alınan problemin çözümü için, bireyin zihin ve zaman açısından belli bir olgunluk süreci geçirmesinin önemlidir. Kuluçka tekniğinde kullanılan öge biliş’tir. Bu teknikle amaçlanan ise; ele alınan konu ya da sorunun, katılımcının zihni süreçten geçirilmesi yoluyla soyut kavram oluşturmak, biçiminde ifade edebiliriz.

Not alma tekniği: Not alma tekniği, tasarımcının ele alınan probleme ilişkin akla gelen tüm çözüm olasılıklarını kâğıda not ederek, hızlıca çizim, taslaklar yapma ve yaratıcı zihni, düşün yolla problem hakkında çokça çözüp bulma temeline dayanır. Not alma tekniğinde kullanılan öge, yazı ve çizim'dir (eskiz). Not alma tekniğinin amacı; ele alınan problemin çözümüne ilişkin zihni ve düşün sürecinde işin içinde olduğu uygulama yoluyla somut kavram oluşturmaktır.

Sentez yöntemi: Sentez yöntemi, farklı düşüncelerin uyumlu biçimde bir araya getirilmesiyle uygulanır. Sentez yönteminde kullanılan öge biliş’tir. Bu yöntem, katılımcıdan ele alınan konu ya da soruna ilişkin, zihin-düşün yoluyla soyut kavram oluşturmasını sağlamayı amaçlamaktadır.

Gözlemler: Gözlem tekniği, bakma, gözden geçirme, denetleme ve inceleme biçiminde, sanatçıların yaratıcılıkta yararlandıkları esin kaynağı unsurları tasarım sürecinde öne çıkarır (Becer, t.y., s. 47-49). Gözlem tekniğinde kullanılan öge görsel'dir. Bu teknikle amaçlanan, katılımcının ele aldığı konu ya da sorunu gözlem yoluyla, somut kavram oluşturmaktır.

Görsel beyin firtınası (Visual brainstorming): Görsel beyin firtınası yöntemi, brainstorming'un görsel alana dönüşümüyle geliştirilmiş bir tekniktir. Görsel beyin fırtınasında süreç, katılımcıların tasarım konusu ya da sorunuyla ilgili görüşlerini, A5 ebadında kâğıtlara çizerek (eskiz), görselleştirmesiyle gerçekleşir. Bu süreç tamamlandığında katılımcılar çizimlerini yöneticiye (öğretmene) teslim eder. İlgili süreç yöneticisi, çizimleri tahta ya da panoya asar ve süreç bu görseller üzerinden devam ettirilir. Görsel beyin firtınası yönteminde kullanılan öge görsel'dir. Bu yöntemle amaçlanan; uygulama yoluyla ele alınan konu hakkında katılımcıda somut kavram oluşturmaktır.

Grafik tasarımcı ile beyin fırtınası: Grafik tasarımcı ile beyin fırtınası yönteminde süreç, öğretmen yerine grafik tasarımcı ile yönetilir. Yönetici, konu ile ilgili problemi ortak bir görsel bellek oluşturmak için, süreci sözel sunumdan çok, resimlerle yönetir. Bununla birlikte, ilgili yöntemin uygulanması çok yaygı̊n değildir (Van Der Lugt, 2000, s.510-511). Grafik tasarımcı ile beyin firtınası yönteminde kullanılan öge, görsel örnekleme'dir. Bu yöntemden amaçlanan ise; ele alınan konu hakkında uygulama yoluyla, somut kavram oluşturma, biçiminde ifade edebiliriz.

Linkografi: Linkografi grafik tarzı çizim ağırlıklı görsel bir sunum tekniğidir. Linkografi bir konu hakkında birbiriyle bağlantılı görsellerin sıralı adımlarını içerir (Kan ve Gero, 2005, s. 230). Bu nedenle, linkografi yöntemi birbiri ardı sıra ilerleyen bir görsel analiz süreci olarak tanımlanabilir. Bu sıralı görseller arasındaki bağlantı gözlemlenip, akıl yürütmeyle araştırılabilir hale getirilir. Linkografi yönteminde süreç, çözümü istenen tasarım problemi hakkında oluşturulan görselin panoya iliştirilmesiyle başlar ve bunu bağlantılı diğer görseller izler. Bu yöntemde önemli olan, görsel sunumlar arasındaki anlaşılır bağlantıdır. Bununla birlikte, A ve B fikirleri arasındaki bağlantı ile B ve C fikirleri arasındaki bağlantıların varlığı, otomatik olarak A ve C fikirleri arasında bir bağlantı olduğu anlamına gelmez. Linkografi yönteminde ardışıklık önemli bir unsurdur. $\mathrm{Bu}$ yöntemde çizimler, görselleştirdiği fikri açıklayan bir başlıkla birlikte panoya asılır. Tasarımcılar bu aşamada, gerek görülürse, tekrar çizim (eskiz) yaparak görselleştirmeye devam edebilir. Böylece süreç, önceki fikirlerle bağlantı kurarak, yeni fikirlerin puanlanmasıyla sonlandırılır. Linkografi yönteminde kullanılan öge görsel'dir. Bu yöntemin amacı; ele alınan konu ya da sorunu uygulama yoluyla, somut kavram oluşturma, biçiminde ifade edebiliriz.

Braindrawing (Düşüncenin görselleştirilmesi): Düşüncenin görselleştirilmesi olarak tanımlayabilecğimiz "braindrawing" yöntemi, katılımcıların fikirlerini kâğıtlara çizip, aktarmasıyla başlar. Daha sonra katılımcılar çizimlerini birbirleriyle değiştirek, kağıtlara çizmeye devam ederler. Bu yolla mevcut fikirleri geliştirilmeye çalışırlır. Bu süreç, genellikle, dört ile altı kez tekrarlanır. Bu yöntemde katılımcıların birbirlerinin fikirlerini çizimlerle geliştirmeleri söz konusudur (Van Der Lugt, 2000, s. 521-522). Braindrawing yönteminde kullanılan öge görsel'dir. Bu yöntemden amaçlanan ise: konuyu uygulama yoluyla, somut kavram oluşturmaktır.

Yukarıda sözü edilen öğretim yöntem ya da tekniklerin, kullandıkları öge, yol ve ulaşmak istedikleri amaç açısından analizi, Tablo 2'de verilmiştir. 
Tablo 2

Eğitim, Sanat Eğitimi ve Grafik Tasarım Eğitiminde Kullanılan Yöntemlerin Kullandıkları Öge, Yol ve Ulaşmak İstedikleri Amaçlar

\begin{tabular}{|c|c|c|c|c|}
\hline Öğretim Yöntem ve Teknikler & $\begin{array}{l}\text { Uygulama } \\
\text { eğitim alanı }\end{array}$ & $\begin{array}{c}\text { Kullanılan } \\
\text { öge(ler) }\end{array}$ & Kullanılan yol(lar) & $\begin{array}{c}\text { Ulaşmak istenen amaç } \\
\text { (öğrenim çıktısı) }\end{array}$ \\
\hline Sunuş Yoluyla Öğretim & Eğitim & Sözel & Soru-yanit & Soyut kavram oluşturma \\
\hline Buluş Yoluyla Öğretim & Eğitim & $\begin{array}{l}\text { Sözel- } \\
\text { örnekleme }\end{array}$ & Tartışma & $\begin{array}{c}\text { Somut-soyut kavram } \\
\text { oluşturma }\end{array}$ \\
\hline Araştırma-Soruşturma Yoluyla Öğretim & Eğitim & Sözel & $\begin{array}{l}\text { Araştırma-işlem ve } \\
\text { uygulama }\end{array}$ & Soyut kavram oluşturma \\
\hline Anlatım ve İşbirliğine Dayalı Yöntem & Eğitim-Sanat & İletişim & İşbirliği ve araştırma & $\begin{array}{c}\text { Somut-soyut kavram } \\
\text { oluşturma }\end{array}$ \\
\hline Soru-Yanit & Eğitim-Sanat & Sözel & Tartışma & Soyut kavram oluşturma \\
\hline Sorun Çözme & Eğitim-Sanat & Çözümleme & $\begin{array}{l}\text { Araştırma-işlem ve } \\
\text { uygulama }\end{array}$ & $\begin{array}{c}\text { Somut-soyut kavram } \\
\text { oluşturma }\end{array}$ \\
\hline Gösterme & Eğitim-Sanat & Görsel-işitsel & Uygulama & Somut kavram oluşturma \\
\hline Drama & Eğitim-Sanat & Sözel-eylem & Uygulama & $\begin{array}{c}\text { Somut-soyut kavram } \\
\text { oluşturma }\end{array}$ \\
\hline Tartışma & Eğitim-Sanat & Sözel & Tartışma & $\begin{array}{c}\text { Somut-soyut kavram } \\
\text { oluşturma }\end{array}$ \\
\hline Öyküleştirme & Eğitim-Sanat & Sözel & Rol & $\begin{array}{c}\text { Somut-soyut kavram } \\
\text { oluşturma }\end{array}$ \\
\hline Grup Çalışması & Eğitim-Sanat & İletişim & İşbirliği & $\begin{array}{c}\text { Somut-soyut kavram } \\
\text { oluşturma }\end{array}$ \\
\hline Beyin Fırtınası & Eğitim-Sanat & Sözel & Fikir üretme & $\begin{array}{c}\text { Somut-soyut kavram } \\
\text { oluşturma }\end{array}$ \\
\hline Dikey ve Kapsamlı Düşünme & Grafik tasarım & Sözel & Zihin-düşün & Soyut kavram oluşturma \\
\hline Yaratıcı Grup Toplantıları (Brainstorming) & Grafik tasarım & Sözel & Fikir üretme & Soyut kavram oluşturma \\
\hline Kuluçka Tekniği & Grafik tasarım & Biliş & Zihin-düşün & Soyut kavram oluşturma \\
\hline Not alma Tekniği & Grafik tasarım & $\begin{array}{l}\text { Yazı-çizim } \\
\text { (eskiz) }\end{array}$ & $\begin{array}{l}\text { Zihin-düşün ve } \\
\text { uygulama }\end{array}$ & Somut kavram oluşturma \\
\hline Sentez Yöntemi & Grafik tasarım & Biliş & Zihin-düşün & Soyut kavram oluşturma \\
\hline Gözlemler & Grafik tasarım & Görsel & Gözlem & Somut kavram oluşturma \\
\hline $\begin{array}{l}\text { Görsel Beyin Firtınası (Visual } \\
\text { Brainstorming) }\end{array}$ & Grafik tasarım & Görsel & $\begin{array}{l}\text { Zihin-düşün ve } \\
\text { uygulama }\end{array}$ & Somut kavram oluşturma \\
\hline Grafik Tasarımcı ile Beyin Fırtınası & Grafik tasarım & Görsel & Uygulama & Somut kavram oluşturma \\
\hline Linkografi & Grafik tasarım & Görsel & Uygulama & Somut kavram oluşturma \\
\hline $\begin{array}{l}\text { Braindrawing (Düşüncenin } \\
\text { görselleştirilmesi) }\end{array}$ & Grafik tasarım & Görsel & Uygulama & Somut kavram oluşturma \\
\hline
\end{tabular}

Tablo 2'ye bakıldığında, genel eğitim ve sanat eğitiminde uygulanan öğretim yöntemleri içerik açısından sözel ağırlıklı öge(ler) kullandığını görüyoruz. Sıklıkla kullanılan bu ögeyi, sırasıyla; iletişim, biliş, çözümleme ve görsel ögeleri izlemektedir. İlgili yöntemlerin amaca ulaşmada tutturdukları yolun ise, düşünsel (zihni süreç) olduğu görülmektedir. Bu öğretim yöntemlerin ulaşmak istedikleri amaç açısından, çoğunlukla soyut bir öğrenim çıktısını hedeflediklerini söyleyebiliriz. Bu bulgu, öğretim yöntemlerinin aynı amaca ulaşmada benzer araçlar kullanabileceği biçiminde yorumlanabilir.

Grafik tasarım eğitimi açısından Tablo 2'ye bakıldığında, uygulanan öğretim yöntemlerinde içerik açısından yaygın biçimde, "görsel” öge kullanıldığını görüyoruz. Grafik tasarım eğitiminde uygulanan öğretim yöntemlerinin, öğretim hedeflerine ulaşmada kullandığı yol ise, çoğunlukla "uygulama" olmaktadır (Tablo 2). Grafik tasarım eğitiminde uygulanan öğretim yöntemlerinin varmak istediği amaç ise, genellikle "somut" bir öğrenim çıktısı olarak karşımıza çıkmaktadır. Buna göre, Tablo 2'deki veriler, grafik tasarım eğitiminde uygulanan öğretim yöntemlerin kullandıkları öge; yol ve öğrenim çıktısı olarak hedefledikleri amacın, genel eğitim alanında uygulanan öğretim yöntemlerinden farklı olduğunu göstermektedir.

Tablo 2'deki veriler dikkate alındığında, öğretim yöntemlerinde ulaşılmak istenen amaca göre, kullanılan öge ve yolun değişebileceğini söylemek mümkündür. Buna göre, öğretim yöntemlerinin ana eksenini belirleyen unsurun öğrenim çıktısının niteliği olduğunu söyleyebiliriz. Bu bulgu, grafik tasarım eğitiminde uygulanan iki öğretim yöntemi üzerinden incelenmeye değerdir. Tablo 2'de yer alan; Yaratıcı Grup Toplantıları yöntemi öğretim çıktısı olarak, soyut bir amaca yönelirken, sözel ögeyi kullanmaktadır. Görsel Beyin Fırtınası (Visual brainstorming) yöntemi ise, somut bir amaca ulaşmayı hedeflerken, görsel ögeden yararlanmaktadır. Öğretim yöntemlerinin, öğrenim çıktılarının niteliğine göre kullandıkları ögeleri belirlemeleri, kendi içinde tutarlı olduğu söylenebilir. Buna göre, grafik tasarım eğitiminde kullanılan yöntemlerin ulaşmak istedikleri amacın, öğrenim çıktısı açısından somut ya da soyut olma durumuna göre, kullandıkları ögenin de değişebileceğini söyleyebiliriz. Tablo 2'deki verileri, bu bulgu açısından incelediğimizde, grafik tasarım eğitiminde kullanılan yöntemlerin soyut bir öğrenim çıktısı hedeflediklerinde, yaygın bir biçimde, sözel öge kullanılırken, somut bir öğrenim çıktısı amaçladıklarında ise, genellikle görsel ögeyi kullandıkları görüyoruz. Diğer bir ifadeyle, grafik tasarım eğitiminde kullanılan 
öğretim yöntemleri somut bir amaca yönelmişse; "görsel”, soyut bir amacı hedeflemiş ise, "sözel” ögeyi kullanmaktadır. Bu durumda, grafik tasarım eğitiminde uygulanacak bir öğretim yönteminde kullanılan ögenin ana belirleyicisinin, öğrenim çıktısının somut ya da soyut olma niteliğine göre değişebileceği söylenebilir.

\subsection{Günümüzde Grafik Tasarım Eğitiminde Yöntem Açısından Arayışlara İlişkin Bulgular}

Tasarım eğitiminin en önemli özelliklerinden biri görsel düşünme’yi öğrenmektir. Bu yönüyle tasarım eğitimi bir tür düşünme yöntemi eğitimi olarak görülebilir (Özderin, 2019, s. 528). Günümüzde sanat eğitimi önemli bir zihinsel etkinlik olarak değerlendirilebilir (San, 2018'den aktaran Özderin, 2019, s. 520). Böylesi bir bakış açısı, Leonardo da Vinci'nin "sanatta uygulamaya elvermeyen teoriyi anlamsız, teoriye dayanmayan uygulamayı da kısır sayan" anlayışı ile anlam kazanmaktadır (Türker, 2005, s. 57). Grafik sanatlar alanında tasarımcı ele aldığı bir tasarım problemini sonuçlandırmak, görsel biçim vermek için hali hazırdaki veriden yola çıkarak, alışılmadık bir çözüme ulaşmaya çalışır (Becer, t.y., s. 45). Bu bağlamda tasarım eylemi, bilgileri anlamlı bütünler halinde yorumlayarak, görsel bir biçimle ifade edilip, iletilebilen bir oluşum olarak görülebilir (Akyıldız Hatırnaz, 2010'dan aktaran Pektaş Turgut, 2016, s. 205). Bu durumda, tasarım öğrencisi, somut görsel üretimin analitik yönlerini öğrenerek, tasarım çalışmalarında zihni eyleme daha çok yönelmelidir (Özderin, 2019, s. 527-528). Esasında, grafik tasarımda gelinen nokta, Rutherford'un (2015, s. 90) vurguladığı gibi, tasarım programlarının çağın endüstri ve teknolojik gelişmişliğine uygun olarak düzenlenmesinin gereğini ortaya koymaktadır. Günümüz tasarım sorunlarının çözülmesi, tasarım ürün talebinin karşılanması açısından eğitim programları, öğrencilerin bilişsel yeteneklerini ve yaratıcı düşünmelerini öne çıkarmayı teşvik etmeli, yeni uygulama ve eğilimlere yer vermelidir. Bundan dolayı, günümüz grafik tasarım eğitimi daha karmaşık bir hal alabilir (Margolin, 2012, s. 1) ancak, tasarım öğrencisine görsel düşünme'nin yanında analitik düşünme becerilerini de geliştirmesi açısından fırsatlar sunabilirsek, günümüz tasarım ihtiyacını karşılayabilecek daha yaratıcı ürünlerle karşılaşmamız mümkün olabilir.

$\mathrm{Bu}$ araştırmadan elde edilen verilerden yola çıkarak, grafik tasarım eğitiminde uygulanan yöntemlerin özellikle, analitik yönden günün koşullarına göre geliştirilmesinin bir gereklilik olduğunu söyleyebiliriz. Dolayısıyla, günümüz grafik tasarım eğitiminde, görsel düşünme ve analitik düşünmeyi birlikte dengeli biçimde harmanlayacak yeni bir öğretim yöntemine ihtiyaç olabilir. Buna göre, mevcut öğretim yöntemlerinin günümüz koşullarıyla örtüşen yönlerini koruyarak, analitik yönden bazı eklemeler yaparak daha bütüncül bir yaklaşım geliştirilmesi mümkündür.

\section{Sonuç, Tartışma ve Öneriler}

$\mathrm{Bu}$ araştırma sonucunda, eğitim alanında uygulanan öğretim yöntemlerinin sözel ağırlıklı öge kullanarak, soyut bir öğrenim çıktısını hedeflerken, grafik tasarım eğitiminde uygulanan öğretim yöntemlerinin, kapsamlı biçimde "görsel" öge kullanarak, "somut" bir öğrenim çıktısını hedefledikleri ortaya konmuştur. Bu sonuç, grafik eğitiminde uygulanacak bir öğretim yönteminde ana unsurları ortaya çıkarması bakımından kayda değerdir. Bu araştırmanın ulaştı̆̆ diğer sonuç ise, genel eğitim, sanat eğitimi ve grafik tasarım eğitiminde uygulanan öğretim yöntemlerinde kullanılan ana ögenin (görsel-sözel) belirleyicisinin, öğrenim çıktısının niteliği (somut-soyut) olduğudur. $\mathrm{Bu}$ sonuç bize, öğretim yöntemi geliştirmede ana unsurun öğrenim çıktısının niteliği olduğunu göstermesi açısından önemlidir.

$\mathrm{Bu}$ araştırma ile, grafik tasarım eğitiminde uygulanan öğretim yöntemlerinde görsellik, genel eğitim alanında uygulanan öğretim yöntemlerinde ise sözelliğin ön plana olduğu ortay konmuştur. Bu sonuç, grafik tasarım eğitiminde görsel düşünme'nin, genel eğitim alanında ise; analitik düşünme'nin baskın olduğunu göstermesi bakımından kayda değerdir. Bununla birlikte günümüzde özellikle gelişmiş teknoloji koşullarında her iki düşünmeye eşit biçimde ihtiyaç vardır. Özellikle, grafik tasarım gibi günlük hayata sunan ürünler üreten bir alanda her iki düşünme biçiminden yararlanmak yaşamsal önemdedir. Dolayısıyla, günümüz grafik tasarım eğitiminde görsel düşünme ve analitik düşünmeye dengeli biçimde yer verecek bütüncül, yeni bir öğretim yaklaşımına ihtiyaç olduğu görülmektedir.

Sonuç olarak; günümüz grafik tasarım eğitiminde özellikle, yükseköğretim düzeyinde öğrencilerin grafik tasarım problemlerini çözmede "görsel" öge kullanarak, uygulama ağırlıklı yapısıyla somut bir öğrenim çıktısına dönüştürecek öğretim yönteminin ana ekseninin; görsel düşünme ve analitik düşünme üzerine kurulmasının günümüz koşullarında geçerli nedenlerinin olduğu söylenebilir. Bugün, grafik tasarım eğitiminde öğrencilerin biçimsel ve analitik anlamda karar verme becerisinin geliştirilmesi ve bunun müfredata yansitılması, tasarımcı adayı öğrencilerin alanda karşılaşacağı zorluk ve sorunlarla baş etmesi açısından önemlidir (Margolin, 2012, s. 1). $\mathrm{Bu}$ nedenle, öğretim yöntemleri yeni baştan tanımlanmalı, öğrencileri düşünmeye sevk eden, düşüncelerini açıkça ifade etmeyi öğreten öğretici (didaktik) yaklaşımlar geliştirilmelidir (Vukic, 2012, s. 3). Bu bağlamda tasarım eğitimi geliştirilip, değiştirilmeli ve alana özgü yeni bir düşünce yöntemi tanımlanmalıdır. Tasarım yöntemlerinin yaratıcı potansiyeli yükseköğretimde düzeyinde verilen eğitimde yeniden tanımlanarak, önemi vurgulanmalıdır. 
$\mathrm{Bu}$ bağlamda yeni eğitim programları hem eğitici hem dönüştürücü olmalı ve öğrenciye değişiklik yapabilme firsat1 verebilmelidir (Vukic, 2012, s. 3).

Grafik tasarım alanında bir tasarım problemini çözmede ana bileşenin görsellik olduğuna kuşku yoktur. Bu nedenle grafik tasarım eğitiminde denenen yöntem ve tekniklerin geleneksel öğretim yöntemlerinden ayrıldı̆̆ı en önemli nokta görsellik'tir. Bu durumu destekler biçimde, Van Der Lugt (2000, s. 521-522), görsel anlatımın yaratıcı problem çözme sürecine dâhil edildiği braindrawing (brainsketching) modelini örnek göstererek, fikirlerin görselleştirilmesi yoluyla yaratıcı problem çözme sürecinin görsel versiyonunun sürece dahil edilmesi gerektiğini belirtmektedir. Bu çalışmanın ulaştığı kayda değer sonuçlara dayanarak, grafik tasarım eğitiminde günümüz koşullarına cevap verebilen, iletişimi yüksek tasarımların oluşabilmesi için, uygulanacak eğitim yöntemlerinde görsel düşünme faktörünün, bir görsel öge gibi tasarım problemini çözme aracı olarak kullanılmasını önerebiliriz. Ulaşılmak istenen amaç; somut bir grafik tasarım ürünü olduğuna göre, kullanılacak öge de ana unsurun görsellik olması olağan olmakla birlikte, günümüz grafik tasarım öğretiminde analitik düşünmenin de sürece dahil edilmesi gerekmektedir. Analitik düşünmeyi geliştirmek için öğretim yöntemlerinde sözel ve biliş ögelerinin de işe koşulması zorunludur. Buna göre, grafik tasarım eğitiminde uygulanacak öğretim yöntemlerinin içerikleri, öğrencilerin bilişsel gelişmelerini de sağlayacak biçimde, görsel düşünme becerilerinin desteklenmesinin yanında, analitik düşünme becerilerinin de ön plana çıkarılarak, bütüncül bir yapıda olması gerekir. Buna göre, günümüz grafik tasarım eğitim alanına önerilecek yeni bir öğretim yöntemin kuramsal temellerinin görsel düşünme ve analitik düşünme üzerine kurulu, bütüncül bir yaklaşımla geliştirilmesi mümkün olabilir. Grafik tasarım eğitiminde, öğrencilerin tasarım problemlerini çözmelerini destekleyecek bütüncül bir öğretim yönteminin kuramsal temelleri böylece ortaya konurken, önerilecek yeni öğretim yaklaşımında öne çıkması olası pratik kuralları da aşağıdaki gibi siralayabiliriz:

- Grafik tasarım sürecinde öğretmen, öğrencinin yaratıcı düşünme becerisini desteklemek için açık-uçlu sorular sorarak, tasarım problemine olası çözüm önerilerinin geliştirilmesini teşvik ederek derse başlayabilir. Bu aşamada ağırlıkla sözel öge kullanılabilir.

- Bu aşamadan sonra öğretmen, öğrencinin analitik düşünme becerisini desteklemek için olası çözüm önerilerini günün koşullarına uyumu açısından öğrencisini kendisine sorgulatabilir. Bu aşamada da ağırlıklı sözel öge kullanılabilir. Bu evre, gerektiğinde, sözel ögenin yanında, yazı ve çizimin de işe koşulduğu hem analitik hemde görsel düşünme ögeleriyle desteklenebilir.

- İzleyen aşamada ise öğretmen, görsel düşünme ve analitik düşünme süreçlerinden elde edilen verilerin, görsel öge kullanılarak ifade edilmesi; görselleştirilmesi teşvik edilmelidir. Bu aşamada ağırlıkla görsel öge kullanılabilir. Bu evrede, elde edilen görsellerin ele alınan tasarım probleminin çözümüne odaklanması çok önemlidir.

- Bu aşamadan sonraki son evre, çözüm odaklı görselin uygulama yoluyla öğrenim çıktısı olarak ürüne dönüşmesi süreci ile ilgilidir. Öğrenim çıktısı somut olduğu için, öğretim yönteminin görsel yoğunluklu, eylemsel ve son evresi de mutlaka bir tasarım ürünüyle sonlanmalıdır.

$\mathrm{Bu}$ yaklaşımla, grafik tasarım eğitiminde uygulama yoluyla ana öge olarak görselliğin kullanıldığı, bununla birlikte, analitik düşünmenin de eşit ağırlıkla işe koşulduğu, somut bir öğrenim çıktısı olarak, özgün bir grafik tasarım ürünüyle sonuçlanan bir süreç gerçekleştirilebilir. Günümüz grafik tasarım eğitiminde, ihtiyaca cevap verebilecek yeni bir öğretim yaklaşımının pratik aşamaları yukardaki gibi ortaya konabilir. Günümüz grafik tasarım eğitiminde önerilecek yeni bir öğretim yönteminde ortaya atılan bu kuramsal temel, aşama ve kurallar ancak, esnek bir atölye ortamında, öğrenciye keşfetme duygusu verecek bir serbestlik içinde, öğrenci merkezli bir öğrenme ikliminde uygulanabilir olacağını ayrıca vurgulamamız gerekmektedir. Son olarak, sanat da dahil tüm alanlardaki eğitim ve öğretim, toplumların ortak geleceğini biçimlendiren ve yarınlarını değerli kılan yegâne alan olduğunu vurgulamamız gerekir. Dolayısıyla, bu alanda yapılacak çalışmaların artması ve uygulamaya konması son derece önemlidir. Pawlak'ın (2016, s. 32-35) belirttiği gibi, yaratıcı bir eğitim ve buna bağlı olarak cesaret verici bir öğrenme ortamı, bir toplumun gelecek yüzyıllardaki başarısının anahtarı olabilir.

\section{Kaynakça}

Ayaydın, A. (2009). Sanatın görsel dili. A. O. Alakuş ve L. Mercin (Eds.), Sanat eğitimi ve öğretimi (s.111-123) içinde. s.111-123. Ankara: Pegem Akademi.

Becer, E. (t.y.). Yaratıcılık ve grafik tasarım. Erişim adresi: https://earsiv.anadolu.edu.tr/xmlui/bitstream/handle/ 11421/1032/98748.pdf? sequence=1

Beyin fırtınası tekniği. (t.y.). Erişim adresi: www.montessoridunyasi.com/beyin-firtinasi-teknigi/ 
Beyreli, L., \& Sönmez, H. (2017). Bloom taksonomisi ve yenilenmiş Bloom taksonomisi ile ilgili Türkiye'de yapılan çalışmaların odaklandığı araştırma konuları. International Journal of Languages' Education and Teaching, 5(2), 213-229. doi: http://doi.org/10.18298/ijlet.1738

Büyüköztürk, Ş., Kılıç Çakmak, E., Akgün, Ö. E., Karadeniz, Ş., \& Demirel, F. (2009). Bilimsel araştırma yöntemleri. (3. Baskı). Ankara: Pegem Akademi.

Cansız Aktaş, M. (2014). Nitel veri toplama araçları. M. Metin (Ed.), Eğitimde bilimsel araştırma yöntemleri (s.337-371) içinde. Ankara: Pegem Akademi.

Cheung, M. (2011). Creativity in advertising design education: An experimental study. Instr Sc., 39, 843-864. doi: http://doi.org/10.1007/s11251-010-9157-y

De Mozota, B. B. (2005). Tasarım yönetimi. (S. Kaçamak, Çev.). İstanbul: MediaCat Kitapları.

Dikmen, B. (2012). Değişen dünyada kültür, sanat ve bilim ilişkisi. Batman Üniversitesi Yaşam Bilimleri Dergisi, 1(1), 137-144. Erişim adresi: https://dergipark.org.tr/tr/download/article-file/313537

Drama tekniği-Montessori Dünyası. (t.y.). Erişim adresi: www.montessoridunyasi.com/drama-teknigi/

Gösterip yaptırma yöntemi nedir?. (t.y.). Erişim adresi: www.ozelogretm.hacettepe.edu.tr/grup3/gosterpy.php

Hayırsever, F. (2002). İlköğretim okullarında uygulanan küme çalışması yönteminin değerlendirilmesi. Milli Eğitim Dergisi, 153-154(Kış-Bahar), 1-10. Erişim adresi: http://dhgm.meb.gov.tr/yayimlar/dergiler/milli_ egitim_dergisi/153-154/hayirsever.htm

İşbirliğine dayalı öğrenme yöntemi. (t.y.). Erişim adresi: www.ozelogretm.hacettepe.edu.tr/grup3/sbrlg.php

Kan, J. W. T., \& Gero, J. S. (2005). Entropy measurement of linkography in protocol studies of designing. J. S. Gero and N. Bonnardel (Eds), Studying designers' 05, 2005 key centre of design computing and cognition, university of Sydney (p. 229-245) içinde. Erişim adresi: https://www.researchgate.net/publication/ 242450177_ENTROPY_MEASUREMENT_OF_LINKOGRAPHY_IN_PROTOCOL_STUDIES_OF_DESI GNING

Kara, Y., \& Çam, F. (2007). Yaratıcı drama yönteminin bazı sosyal becerilerin kazandırılmasına etkisi. Hacettepe Üniversitesi Eğitim Fakültesi Dergisi, 32, 145-155. Erişim adresi: http://www.efdergi.hacettepe.edu.tr/ yonetim/icerik/makaleler/586-published.pdf

Kırışoğlu, O. (2009). Sanat, kültür ve yaratıcılık. Ankara: Pegem Akademi Yayıncılık.

Kim, M. J., Ju, S. R., \& Lee, L. (2015). A cross-cultural and interdisciplinary collaboration in a joint design studio. International Journal of Art \& Design Education, 34(1), 102-120. doi: 10.1111/jade.12019

Margolin, V. (2012). Grafik tasarım eğitimi ve toplumsal değişimin getirdiği zorluklar. (L. Tonguç Basmacı, Çev.). Grafik Sanatlar Üzerine Yazllar: Grafikerler Meslek Kuruluşu, 123. Erişim adresi: http://gmk.org.tr/uploads/news/file-1457210108324006210.pdf

Öğretim yöntemleri. (t.y.). Erişim adresi: https://ogryontem.wordpress.com/beyn-frtnas/

Özderin, S. (2019) Grafik tasarım eğitiminde akademik ilkeler. Uluslararası Sosyal Araştırmalar Dergisi, 12(66). 517-532. doi: 10.17719/jisr.2019.3603

Özsoy, V., \& Alakuş, A. O. (2009). Görsel sanatlar eğitiminde özel ögrretim yöntemleri. Ankara: Pegem Akademi.

Pawlak, A. M. (2016). Fostering creativity in the new millennium. Research-Technology Management, 43(6), 3235. doi: 10.1080/08956308.2000.11671393

Pektaş Turgut, Ö. (2016). Tasarım tarihi eğitiminde yeni yöntem ve yaklaşımlar. Ĕgitim ve Öğretim Araştırmaları Dergisi, 5, 204-211. Erişim adresi: http://www.jret.org/FileUpload/ks281142/File/24.ozden_pektas_turgut.pdf

Peng, L., \& Zhang, Y. (2014, 21-22 June). Study on the innovative design of graphic design. Presented notice in 2nd International conference in humanities, social sciences and global business management (ISSGBM 2014). London, England.

Problem çözme yöntemi. (t.y.). Erişim adresi: www.ozelogretm.hacettepe.edu.tr/grup3/problem.php

Ravikumar, R. (2008). The creative problem solving process in graphic design classrooms. Design Principles and Practices: An International Journal 2(2), 49-52. doi:10.18848/1833-1874/CGP/v02i02/38275

Rutherford. (2015). Improving student engagement in commercial art and design programmes. International Journal of Art \& Design Education. 34(1), 89-101. doi: 10.1111/jade.12016 
Sanat. (t.y.). Türk Dil Kurumu güncel Türkçe sözlük içinde. Erişim adresi: https://sozluk.gov.tr/

Soru-cevap yöntemi. (t.y.). Erişim adresi: http://www.ozelogretim.hacettepe.edu.tr/grup3/sorucevap.php

Sönmez, V. (2010). Öğretmen el kitabı. Ankara: Anı Yayıncılık.

Sönmez, V., \& Alacapınar, F. G. (2011). Örneklendirilmiş bilimsel araştırma yöntemleri. Ankara: Anı Yayıncılık.

Tartışma yöntemi. (t.y.). Erişim adresi: https://ogryontem.wordpress.com/tartisma-yontemi/

Tepecik, A. (2002). Grafik sanatlar. Ankara: Detay \& Sistem ofset.

Tepetaş, G. Ş., \& Haktanır, G. (2013). 6 yaş çocuklarının temel kavram bilgi düzeylerini desteklemeye yönelik öyküleştirme yöntemine dayalı bir eğitim uygulaması. Eğitim ve Bilim, 38(169), 62-79. Erişim adresi: http://egitimvebilim.ted.org.tr/index.php/EB/article/view/1680/497

Türker, İ. H. (2005). Bilgisayar destekli grafik tasarımı dersi yöntem önerisi. Presented notice in Proc. 4 Int. Educational Technology Symposium, Sakarya, Turkey. Erişim adresi: https://www.researchgate.net/ publication/322790136_Bilgisayar_Destekli_Grafik_Tasarimi_Dersi_Yontem_Onerisi

Van Der Lugt, R. (2000). Developing a graphic tool for creative problem solving in design groups. Design Studies, 21(5), 505-522. Erişim adresi: https://research.tudelft.nl/en/publications/developing-a-graphic-tool-forcreative-problem-solving-in-design-

Vukic, F. (2012). Yarının tasarımı mı?. (L. Tonguç Basmacı, Çev.). Grafik Sanatlar Üzerine Yazılar: Grafikerler Meslek Kuruluşu, 123. Erişim adresi: http://gmk.org.tr/uploads/news/file-1457210108324006210.pdf

Y. Balaban., \& D. Akdă̆ Satır (Ed.). (t.y.). Grafik tasarım: Medya ve iletişim. Erişim adresi: http://auzefkitap.istanbul.edu.tr/kitap/kok/grafiktasarimu149.pdf 